\title{
ATP-Citrate Synthase
}

National Cancer Institute

\section{Source}

National Cancer Institute. ATP-Citrate Synthase. NCI Thesaurus. Code C107109.

ATP-citrate synthase (1101 aa, $\sim 121 \mathrm{kDa}$ ) is encoded by the human ACLY gene. This protein is involved in both the synthesis of cytosolic acetyl-CoA and the de novo lipid synthesis. 